\title{
The epidemiological profile of malaria in a municipality in the Brazilian Amazon
}

\section{Raquel Alves Fernandes ${ }^{1}$ and Daniela Soares Leite ${ }^{2}$}

${ }^{1}$ Universidade do Estado do Pará. Centro de Ciências Biológicas e da Saúde. Curso de Biomedicina. Campus VIII. Avenida Hiléia, s/no. Agrópolis do Incra. Bairro Amapá. Marabá-PA. Brasil (68502-100). Email: raquelfernadesmba@gmail.com.

${ }^{2}$ Universidade do Estado do Pará. Centro de Ciências Biológicas e da Saúde. Departamento de Morfologia e Ciências Fisiológicas. Campus VIII. Avenida Hiléia, s/no. Agrópolis do Incra. Bairro Amapá. Marabá-PA. Brasil (68502-100). Email: danielaleite@uol.com.br.

\begin{abstract}
Malaria is a tropical disease caused by protozoa of the genus Plasmodium (Aconoidasida: Haemosporida: Plasmodiidae). The Brazilian Amazon is the area with the highest risk of malaria transmission in the country. The aim of this study was to trace the epidemiological profile of malaria patients between 2010 and 2015, in the Municipality of Marabá, State of Pará, North Brazil. Secondary data were used, of Sivepmalaria of the Municipal Health Department of the municipality. The variables analyzed were the incidence autochthonous or imported cases, genus, species of the causative parasite infection during pregnancy and parasitic annual index. Data analysis used the Chi-Square Test, in the Biostat 5.0. The annual parasitic index (IPA) of malaria cases in Marabá in 2010 was 3.7, followed by the year of 2011 with 2.7, from the year 2012 the IPA drops sharply to 0.68 , followed by the years 2013,2014 and 2015, which presented an IPA of 0.1, 0.07 and 0.01 respectively. Data on the contamination site revealed that $51 \%$ of the cases in the period studied were of imported origin and $49 \%$ were autochthonous, and there was no significant statistical difference between the years. Males were the most affected by the disease $(67 \%)$. The most common parasitic species was Plasmodium vivax. Malaria cases have been reduced over the years, and this is due to several factors, such as better access to the diagnosis and treatment of the disease, to the control of the vectors, and to the constant work of epidemiological surveillance, although underreporting is still a great problem in the measurement of the actual numbers of cases.
\end{abstract}

Keywords: Malaria; Plasmodium; Epidemiology; Environmental health.
Received

July 5, 2018

Accepted

August 27, 2018

Released

August 31, 2018

Full Text Article

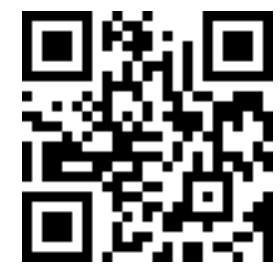

ORCID

(1) 0000-0001-8635-7825

Raquel Alves

Fernandes

(1) 0000-0002-3412-1375

Daniela Soares Leite 


\section{Introduction}

Malaria, also known as maleita, paludism, and tertian or quartan fever, has been reported as the disease of intermittent fevers since antiquity in Chinese and Egyptian writings of 3,000 years BC (Camargo, 2003). The name malaria comes from 'mal'aire' in Italian, which means 'bad air', because it was believed that the disease came from the emanations of fetid marshes (Sanchez et al., 2012). Malaria is one of the most serious parasitic diseases in the world due to the numerous deaths it causes because of its severity (Braz, 2013 et al., Parize et al., 2012). Caused by Protozoa (Aconoidasida: Haemosporida: Plasmodiidae), malaria is transmitted to humans through the bite of female mosquito infected. In Brazil, it is transmitted by three parasitic species, Plasmodium vivax (Grassi \& Feletti, 1890), Plasmodium falciparum (Welch, 1897), and Plasmodium malariae (Feletti \& Grassi, 1889). The P. vivax is responsible for most cases of disease in the country (Brasil, 2013). In addition to transmission through the bite of female mosquito, the disease can also be transmitted by other less common means such as in laboratory accidents, sharing needles or contaminated syringes, blood transfusion and congenital via (Ferreira et al., 2012). In this context of transmission less common means by congenital malaria via increases the risk of disease to the mother and the child and may cause miscarriage, stillbirth, prematurity and low birth weight, and the disease responsible for an important cause of child mortality (Tobón-Castaño et al., 2011). The endemicity of the region where the pregnant woman lies is directly associated with the effect the disease has on pregnant and the fetus or newborn (Alves et al., 1995; Chagas et al., 2009). Malaria has its associated impact the interaction of several factors, such as land use, the changes caused by man, biological, environmental, social, political, and they should be studied in order to create prevention and compliance measures treatment. For effective control of malaria is done, it is necessary that in addition to the identification and intervention of the determining factors, there is also the knowledge of seasonal, cyclical and historical variations of the disease in each location (Braz et al., 2013). Malaria, present in more than 109 countries and territories, is a disease present in the tropical and subtropical regions of the planet, affecting almost $50 \%$ of the population, and annually results in the loss of thousands of lives, with subSaharan Africa accounting for about 90\% of all malaria cases and deaths in the world (Parise et al., 2012). In the world, in the year 2000 were 262 million cases and 839 thousand deaths; in the year 2015 were 214 million cases and 438 thousand deaths (Parise et al., 2012; WHO, 2015).

In Brazil, the number of registered cases of malaria is still high, it focuses mainly in the area of the Amazon, which registers $99 \%$ of cases in the country, mainly caused by P. vivax and P. falciparum (Ferreira et al., 2012; Brito et al., 2016). In the 1940s, the number of malaria cases in Brazil amounted to 6 million, all areas were endemic, except the state of Rio Grande do Sul, and what is now the Federal District. Over the years, the fight against malaria and the economic growth of Brazil, the number of cases and the areas affected by malaria were decreasing (Silva Santelli et al., 2016). Already in the 1960s, cases of malaria in extra-Amazon Region exceeded the cases of malaria in the Amazon Region, the Malaria Eradication Campaign was established and there was a large reduction in cases, which is still ongoing. Between the years 1960-1976, the Amazon Region recorded an average of 80,000 cases of malaria per year. Since 1977, Brazil began a deployment phase of colonization projects, mining, opening roads and installation of hydroelectric plants in the region and because it was an intense migration of people to the 
Amazon Region, which made that in 1989 the cases of malaria reached nearly 560,000 (Loyola et al., 2002; Silva Santelli et al., 2016). From 1990 onwards, malaria in Brazil presented a "saw effect", in a few years the number of cases decreased, and in other years, the number of cases increased; In 1993, 483,367 cases of malaria were reported, in $1999,637,474$ cases, in $2002,349,896$ cases and in 2005 this number rose to 607,751 cases (Brasil, 2013; Silva Santelli et al., 2016). In 2006, with the introduction of therapeutic regimens for first-line artemisinin derivatives for the treatment of P. falciparum, began a decline in the incidence of cases in the following years. In 2006, 550,847 cases were registered, in 2008 there were 315,808 cases, in 2010 there was an increase, with 334,709 cases, in 2011 a decline began, which remains until the present day and in 2014, there were 144,100 cases, the lowest number of cases of the last 35 years in Brazil (Brasil, 2013; Silva Santelli et al., 2016). In 2014, were registered 559 cases of malaria in the Extra-Amazon Region, 54 cases are autochthonous of the States of Bahia, Santa Catarina, São Paulo, Espírito Santo, Mato Grosso do Sul, Piauí, Rio de Janeiro, 273 cases had the Amazon Region as a likely site of infection, and 232 had other countries as a likely site of infection (Brasil, 2015).

In the Amazon Region since the 1870s when it began the cycle of exploitation of rubber in the Amazon, malaria has become a serious public health problem (Ujvari, 2004) Malaria is a regular notifiable disease in the Amazon Region, and has high prevalence in the population living there, its debilitating effects contribute to the occurrence of a decrease in the quality of life of people, so it is responsible for social and economic losses of the population especially of those who live in areas of poor housing and sanitation (Renault et al., 2007; Michael, 2011; Brasil, 2015). The Brazilian Amazon is the area with the highest risk of malaria transmission in the country, this is due to several factors, such as the migration process, prospecting activities, agricultural, livestock, deforestation, construction of hydroelectric, autochthonous areas, occupancy periurban areas, extraction plant, increase in the population of mosquitoes and resistance to antimalarials (Braz et al., 2013; Brito et al., 2016). All the states that make up the Amazon Region showed a reduction of cases between 2000 and 2011; the Acre was the only exception (Brasil, 2015). The state of Maranhão had the largest decrease in the number of cases, with a reduction of $95.5 \%$, followed by Tocantins, with $95.4 \%$, Mato Grosso with 86.1\%, Roraima 61.0\%, Pará $58.8 \%$, Amapá 46.2\%, Rondônia 43.8\% and Amazonas, with a $38.1 \%$ decrease in the number of cases (Brasil, 2013). The Malaria Epidemiological Surveillance Information System (Sivep-Malaria) in 2015 registered in the country, 333,429 cases of malaria in 2010, in 2011 there were 265,382 cases, 2012 had 241,806 cases, in 2013 there were 177,789 cases, 2014 cases with 143,552 cases and 2015 cases with 142,644 cases. There was a reduction in the number of cases in the states of the northern region. This reduction covered all groups of analyzed areas: urban $(-22 \%)$, autochthonous ($22 \%)$, mining $(-43 \%)$, settlement and in the rest of the rural area $(-11 \%)$. (Brasil, 2015).

For the state of Pará, the SivepMalaria in 2015 reported that the state in 2010 had 135,822 cases of malaria, in 2011 there were 115,638 cases, this value reduced to approximately 79,000 cases in 2012, in 2013 there were 24,860 cases, in 2014 there were 11,251 cases, and this number dropped to 9,421 cases in 2015. In 2011, Pará registered a percentage increase in malaria cases in settlements regions (37\%) and mining (82\%) (Brazil, 2013, Brazil, 2015).

Malaria continues to be one of the main public health problems in the world and one of the main causes of morbidity in the Amazon region, which accounts for 
more than 99\% of malaria cases in Brazil (Brasil, 2016). The state of Pará occupies the second place in the ranking of occurrence of cases, despite significant advances in disease control (OPAS, 2018). The State of Pará has been plagued by a process of deforestation of their native vegetation, with the uncontrolled felling of its forests and burned, mainly the south and southeast of the state, where large logging and agropastoral projects are concentrated (Parente et al., 2012). The municipality of Marabá, in the state of Pará, is one of the largest and most important poles in the southeastern region of Pará, and it is of fundamental importance to have a constant evaluation of the incidence of malaria in this area, in order to contribute to the planning of governmental actions in combating the transmission of the disease.

The objective of this study was to trace the epidemiological profile of malaria patients in the Municipality of Marabá, State of Pará, North Brazil, between 2010-2015.

\section{Methodology}

This study is a descriptive crosssectional quantitative study of retrospective performed in the Municipality of Marabá. The samples studied were made up exclusively of secondary malaria data available in the Epidemiological Surveillance Information System (SIVEP/Malária), of the Secretariat of Health Surveillance (SVS) of the Ministry of Health (MS), by through the notification forms of the disease provided by the Department of Health Surveillance, the Municipal Health of Marabá.

Inclusion criteria were reported positive cases of malaria in the municipality of Marabá between January 2010 and December 2015. Exclusion criteria were negative cases and cases of malaria cured in the same period.

Were analyzed the number of positive cases per year (incidence),
Annual Parasite Index (IPA), source of contamination (autochthonous or imported cases), number of cases per unit notifying, distribution of individuals affected by gender, causing parasite species, correlation between infection during pregnancy, and the species of parasite.

The annual parasitic index was calculated using the number of malaria positive tests divided by the total number of the population (used the data from the census and estimates of the Brazilian Institute of Geography and Statistics for the years of study x 1,000 (RIPSA, 2012). Low risk is considered when IPA $<10 / 1,000$ inhabitants, medium risk when IPA 10-49/1,000 inhabitants, and high risk when IPA $>50 / 1,000$ inhabitants (RIPSA, 2012). The results of the variables investigated during the study period were exposed descriptive and quantitative manner, based on retrospective analysis of data on the epidemiological situation of malaria in Marabá.

Para the statistical analysis, the data were submitted to descriptive analysis and comparison of means through the use of Bioestat 5.0. The test used was Chi-square, whose principle is to compare ratios, ie the possible frequency differences between observed and expected frequencies for a given value. Differences were considered significant when the probability (p) the error was less than $5 \%(p<0.05)$.

The realization of this study followed the precepts of the Declaration of Helsinki and Nuremberg Code, as well as the Resolution No. 466/2012, of the National Health Council (Brasil, 2012). The study was conducted after submission and approval by UEPA's Committee on Ethics in Human Research, according to the opinion No. 2075556.

\section{Results}

Between 2010 and 2015 were reported in the Epidemiological 
Surveillance Information System (SIVEPMalaria) 1,760 cases of malaria in the Municipality of Marabá. In 2010, there were $878(49.89 \%)$ positive cases of malaria, in 2011, 661 (37.55\%) positive cases. In the year 2012, 168 (9.54\%) positive cases of malaria were registered, and as of that year, the number dropped drastically, with 29 cases (1.64\%) recorded in 2013. The lowest number of malaria cases occurred in 2014 and 2015, with $19(1.07 \%)$ cases and 05 $(0.28 \%)$ malaria cases, respectively (Table 1).

Table 1. Positive malaria cases from January 2010 to December 2015.

\begin{tabular}{lcccccc}
\hline & $\mathbf{2 0 1 0}$ & $\mathbf{2 0 1 1}$ & $\mathbf{2 0 1 2}$ & $\mathbf{2 0 1 3}$ & $\mathbf{2 0 1 4}$ & $\mathbf{2 0 1 5}$ \\
\hline January & 55 & 42 & 44 & 3 & 2 & 1 \\
\hline February & 68 & 41 & 22 & 6 & 0 & 1 \\
\hline March & 89 & 40 & 18 & 4 & 4 & 0 \\
\hline April & 92 & 51 & 21 & 2 & 1 & 0 \\
\hline May* & 131 & 98 & 20 & 3 & 0 & 0 \\
\hline June & 78 & 90 & 14 & 1 & 3 & 0 \\
\hline July & 48 & 85 & 4 & 3 & 2 & 2 \\
\hline August & 51 & 60 & 11 & 1 & 1 & 1 \\
\hline September & 48 & 49 & 3 & 4 & 1 & 0 \\
\hline October & 39 & 42 & 3 & 1 & 1 & 0 \\
\hline November & 94 & 38 & 3 & 0 & 3 & 0 \\
\hline December & 85 & 25 & 5 & 1 & 1 & 0 \\
\hline Total & $\mathbf{8 7 8}$ & $\mathbf{6 6 1}$ & $\mathbf{1 6 8}$ & $\mathbf{2 9}$ & $\mathbf{1 9}$ & $\mathbf{5}$
\end{tabular}

Source: Research Data. ${ }^{*} \mathrm{P}<0.05$.

The municipality's Annual Parasitic Index (IPA) declined throughout the study period, in 2010 the IPA it was 3.7, in 2011 it was 2.7, in 2012 the IPA drops sharply to 0.68 , followed by the years $2013(0.1), 2014(0.07)$ and 2015 (0.01), respectively (Figure 1).

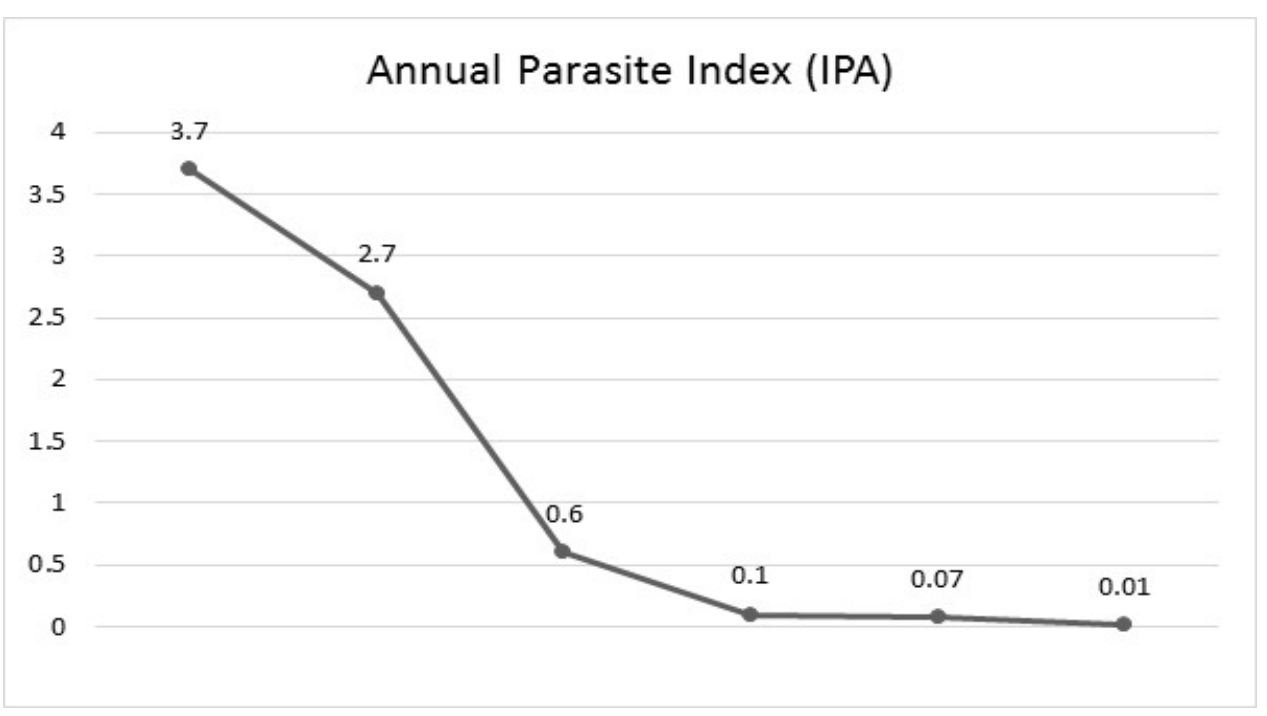

Figure 1. Annual Parasite Index (IPA) from Municipality of Marabá between 2010 and 2015. 
Between 2010 and 2015 malaria cases imported from another municipality, state or country accounted for $51 \%$ of malaria cases in Marabá, while autochthonous cases accounted for $48.87 \%$ of malaria cases in Marabá. Considering the values of autochthonous and imported cases, between 2010 and 2015 there is no statistical difference.

The positive cases of malaria by sex in the period from 2010 to 2015 had a higher frequency observed in the male sex, with $66.78 \%(1,138 / 1,704)$ of the cases, whereas the female sex presented $33.21 \%$ (566 / 1,704). 54 notification forms were incomplete in the gender category.

Among the species and parasitic forms of malaria, in the municipality of
Marabá, in 2010, P. vivax accounted for $92.9 \%$ of cases of malaria, P. falciparum, $3 \%$ of cases of malaria, and cases of mixed malaria among $\mathrm{P}$. vivax and $\mathrm{P}$. falciparum, $3 \%$ of cases of malaria. In $2011,81 \%$ of the cases were caused by P. vivax, $11 \%$ of the cases caused by $\mathrm{P}$. falciparum and $3 \%$ were caused by $\mathrm{P}$. vivax and P. falciparum. In 2012, 82\% of cases were caused by P. vivax, $11 \%$ of cases by P. falciparum and $2 \%$ by P. vivax and P. falciparum (mixed malaria In $2013,86 \%$ of the cases were caused by P. vivax, $9 \%$ by $\mathrm{P}$. falciparum and $4 \%$ by $\mathrm{P}$. vivax and $\mathrm{P}$. falciparum (mixed malaria). In $2014,80 \%$ of cases were caused by P. vivax, $10 \%$ of cases by P. falciparum and $10 \%$ by P. vivax and P. falciparum.

Table 2. Species and parasitic forms of Plasmodium.

\begin{tabular}{lcccccc}
\hline & $\mathbf{2 0 1 0}$ & $\mathbf{2 0 1 1}$ & $\mathbf{2 0 1 2}$ & $\mathbf{2 0 1 3}$ & $\mathbf{2 0 1 4}$ & $\mathbf{2 0 1 5}$ \\
\hline $\begin{array}{l}\text { Plasmodium falciparum } \\
\text { Plasmodium falciparum + Gamete }\end{array}$ & 6 & 61 & 15 & 2 & 1 & 0 \\
\hline $\begin{array}{l}\text { Plasmodium falciparum } \\
\text { Plasmodium vivax * }\end{array}$ & 800 & 445 & 112 & 19 & 8 & 3 \\
\hline $\begin{array}{l}\text { Plasmodium falciparum + } \\
\text { Plasmodium vivax }\end{array}$ & 27 & 19 & 3 & 0 & 1 & 0 \\
\hline $\begin{array}{l}\text { Plasmodium vivax + Gamete } \\
\text { Plasmodium falciparum }\end{array}$ & 2 & 4 & 1 & 0 & 0 & 0 \\
\hline Gamete of Plasmodium Falciparum & 0 & 5 & 0 & 0 & 0 & 0 \\
\hline Plasmodium malariae & 0 & 0 & 0 & 0 & 0 & 0 \\
\hline $\begin{array}{l}\text { Plasmodium falciparum + } \\
\text { Plasmodium malariae }\end{array}$ & 0 & 2 & 0 & 0 & 0 & 0 \\
\hline $\begin{array}{l}\text { Plasmodium ovale } \\
\text { Total }\end{array}$ & 0 & 0 & 0 & 0 & 0 & 0 \\
\hline
\end{tabular}

Source: Research Data. ${ }^{*} \mathrm{P}<0.05$.

In the year 2010 in Marabá, 11 malaria-positive cases were reported in pregnant women, 10 cases caused by $\mathrm{P}$. vivax (90.9\%) and 1 case by P. falciparum
(9.09\%). In 2011 the numbers of cases of malaria in pregnant women reduced dramatically, having only 1 (9.09\%) case of malaria by P. vivax (Table 3 ). 
Table 3. Positive cases of malaria in pregnant women and the parasite 2010 and 2015 in Municipality of Marabá.

\begin{tabular}{|c|c|c|c|c|c|c|}
\hline & 2010 & 2011 & 2012 & 2013 & 2014 & 2015 \\
\hline Plasmodium falciparum & 1 & 0 & 0 & 0 & 0 & 0 \\
\hline Plasmodium vivax * & 10 & 1 & 0 & 0 & 0 & 0 \\
\hline Plasmodium falciparum Plasmodium vivax + & 0 & 0 & 0 & 0 & 0 & 0 \\
\hline Plasmodium malariae & 0 & 0 & 0 & 0 & 0 & 0 \\
\hline Plasmodium ovale & 0 & 0 & 0 & 0 & 0 & 0 \\
\hline Total & 11 & 1 & 0 & $\mathbf{0}$ & $\mathbf{0}$ & $\mathbf{0}$ \\
\hline
\end{tabular}

Source: Research Data. ${ }^{*} \mathrm{P}<0.05$.

\section{Discussion}

The reduction in the annual number of positive cases of malaria in Marabá, is according to studies conducted in Rio Branco (State of Acre), between 2003 and 2010 (Santos and Silva, 2011), in Rio Preto da Eva (State of Amazonas), between 2008 and 2013 (Brito et al., 2016) and Maranhão State, between 2007 and 2012 (Mesquita et al., 2013), observed a progressive decrease in the total number of positive cases during the study period. This reduction in cases is associated with actions and initiatives to combat malaria in Brazil, however, it is reiterated that it is necessary to constantly improve these actions, to maintain quality and to have a better coverage of them.

Still in this context, the state of Pará in 2013 had a reduction of $69 \%$ in malaria cases compared to the year 2012 (Brasil, 2015). Brazil is also showing a reduction in the number of annual malaria cases, in 2014 it had the lowest number of cases in the last 35 years (Brasil, 2015)

The Annual Parasite Index (IPA) of the municipality of Marabá declined during the study period, in agreement with Sousa et al., (2015) who found results of IPA decline in most of the municipalities of the low Amazonas Pará region, between 2009 and 2013. And Parise et al., (2012) that during the period from 2003 to 2008 found a lowrisk IPA in all the municipalities that make up the micro-regions of Tocantins.
According to the Malaria Elimination Plan in Brazil (Silva Santelli et al., 2016), municipalities in malaria elimination phase are those who have IPA $<10$, the Municipality of Marabá fit this profile and the next step of elimination plan is the prevention of reintroduction of malaria cases in the county.

Considering the values of autochthonous and imported cases, between 2010 and 2013 there is no statistical difference. In disagreement with this study, Renault et al., (2007), during the years of 2004 and 2005, in Belém - Pará, reported the imported cases always superior to the autochthonous cases; Mesquita et al. (2013), during the years 2007 to 2009, in Maranhão, observed a predominance of autochthonous cases in relation to imported cases. However, during the years 2010 to 2012, the imported cases were larger than the autochthonous cases in that location. Parise et al. (2012) also discusses the records of autochthonous cases of malaria in the state of Tocantins, and suggests that the cause of autochthonous cases may be related to the number of river beaches that form the river banks of the state, which are frequented by tourists from various places and may have contributed to the registration of autochthonous cases.

In this context, as the state of Tocantins, Marabá is also a city surrounded by rivers, Tocantins and Itacaiúnas rivers, and the beaches may 
have contributed to recorded cases of malaria, whether autochthonous or imported, since many people come from surrounding cities for leisure time on the beach. And when contracting the disease can be diagnosed in said municipality accounting for an autochthonous case. According to Marques and Gutierrez (1994), the proximity to the rivers suggests that there are many sites suitable for the formation of breeding sites, because they are low and humid areas, where it flows into the river waters favoring the concentration of mosquitoes.

The difference of patients between the genders is a common finding in other studies, as in Municipality of Rio Branco (State of Acre), between 2003 and 2010 (Santos and Silva, 2011), Municipality of Belém (State of Pará), between 2000 and 2011 (Miller et al., 2013), Municipality of Cruzeiro do Sul (State of Acre), in 2013 (Lima and Scherer, 2015), the Lower Amazon (State of Pará), between 2009 and 2013 (Sousa et al., 2015). The populations of both sexes are susceptible to malaria, however, males have higher prevalence of cases due to their exposure to the vector during work activities, such as work in agriculture, timber extraction, road building, mining, hunting and fishing.

The P. vivax was responsible for the highest number of malaria cases between 2010 and 2015, these data corroborate studies in Municipality of Ariquemes (State of Rondônia), between 2005 and 2010 (Ferreira et al., 2012), the Lower Amazon (State of Pará), between 2009 and 2013 (Sousa et al., 2015), in State of Tocantins, between 2003 and 2008 (Parise et al., 2012), in Municipality of Novo Progresso (State of Pará), between 2010 and 2013 (Albarado et al., 2015), in State of Maranhão, between 2007 and 2012 (Mesquita et al., 2013), in Municipality of Rio Branco (State of Acre), between 2003 and 2010 (Santos and Silva, 2011), in Municipality of Sinop (Mato Grosso), between 2003 and 2012 (Granzoto et al., 2015) and in
Municipality of Belém (State of Pará), between 2004 and 2005 (Renault et al., 2007), which had the P. vivax as the most frequent species in malaria infections.

In this context, it can be inferred that the prevalence of malaria cases by $\mathrm{P}$. vivax may be related to the difficulty of starting the treatment early, since the time of formation of the gametes is after 24 hours of the appearance of the first symptoms. This also explains why P. falciparum is less prevalent than P. vivax, since the formation of gametes takes from 7 to 12 days, in addition, there was a change in the therapeutic regimen of P. falciparum, which changed from quinine and doxycycline for combinations with artemisinin derivatives (Brazil, 2013).

Positive cases for malaria in pregnant women, and mostly by P. vivax (90.9\%), corroborate a cohort study conducted between 1993 and 2007, in pregnant women in Colombia, where $73 \%$ of cases infection in pregnant were caused by P. vivax (Tobón-Castaño et al., 2011), and in cohort study conducted in the Amazon Tropical Medicine Foundation in $78 \%$ of cases of malaria are caused by P. vivax (Chagas et al., 2009). However, in a study conducted between 1996 and 2001 the P. vivax and P. falciparum were in very close proportions, $52.8 \%$ and $43.8 \%$, respectively (Jarude et al., 2003). The P. Vivax be more prevalent in pregnant women with malaria in Marabá is explained by the fact that it is the most frequent parasitic species in the Municipality of Marabá.

\section{Conclusion}

By analyzing the distribution of malaria between 2010 and 2015 in the municipality of Marabá, it was found that there was, in general, a reduction in the frequency of reported cases. The IPA presented a reduction over the long years and Marabá presents as a low-risk municipality, the male sex presented the highest rates of the disease, the imported 
and autochthonous cases maintained similar frequencies throughout the years of study, the species P. vivax was the most prevalent during the 6 years analyzed and during pregnancy most cases of malaria were caused by P. vivax.

It is necessary to better fill out the notification forms in the municipality, reducing underreporting, so that the results obtained in epidemiological studies using secondary data have more reliable results.

Despite advances in the fight against malaria, it is necessary to strengthen the service network, providing timely and adequate access to the diagnosis and treatment of malaria, which has a direct influence on the reduction of mortality and complications caused by the disease, as well as the impact transmission control.

\section{Acknowledgments}

To the Municipal Health Secretary of Marabá, Pará State, Brazil, for the logistical support to this study achieve.

\section{Conflict of interest}

Authors declare that they have no conflict of interests.

\section{References}

Albarado, K. V. P.; Sousa, J. R.; Magno, L. D.; Santos, A. C. F.; Rocha, J. A. M.; Pimentel, Z. N. $\mathrm{S}$. Enfoque epidemiológico da malária de 2009 a 2013. Revista de Enfermagem da Universidade Federal Piauí, v. 4, no. 2 , p. 62-68, 2015. https://doi.org/10.26694/ reufpi.v4i2.3159

Alves, M. J. C. P.; Lima, V. L. C.; Rangel, O.; Pignatti, M. G. Malária congênita no Município de Leme-SP. Jornal de Pediatria, v. 71, no. 3, p. 163-165, 1995.

Brasil. Conselho Nacional de Saúde. Resolução No. 466, de 12 de dezembro de 2012. Available from: <http://conselho. saude.gov.br/resolucoes/2012/reso466.pdf> . Accessed on: Jun. 03, 2018.
Brasil. Ministério da Saúde. Situação epidemiológica da malária no Brasil, 2000 a 2011. Boletim Epidemiológico, Secretaria de Vigilância em Saúde, Brasília: v. 44, 16 p., 2013.

Brasil. Ministério da Saúde. Malária: Monitoramento dos casos no Brasil em 2014. Boletim Epidemiológico, Secretaria de Vigilância em Saúde, Brasília, v. 46, no. 25, 5 p., 2015.

Braz, R. M.; Duarte, E. C. D.; Tauil, P. L. Caracterização das epidemias de malária nos municípios da Amazônia Brasileira em 2010. Cadernos de Saúde Pública, v. 29, no. 5, p. 935-944, 2013. https://doi.org/10.1590/ S0102-311X2013000500011

Brito, D. M.; Vital, W.; Santana, L. K. L. Incidência de malária no Município de Rio Preto da Eva-AM no período de 2003 a 2013. Scientia Amazonia, v. 5, no. 1, p. 82-92, 2016.

Camargo, E. P. Malária, maleita, paludismo. Ciência \& Cultura, v. 55 , no. 1 , p. 26-29, 2003.

Chagas, E. C. S.; Nascimento, C. T.; Santana Filho, F. S.; Bôtto-Menezes, C. H.; MartinezEspinosa, F. E. Malária durante a gravidez: efeito sobre o curso da gestação na Região Amazônica. Revista Panamerica Salud Publica, v. 26, no. 3, p. 203-208, 2009.

Cordeiro, C. E. S.; Filomeno, C. R. M.; Costa, C. M. A.; Couto, A. A. R. A. Perfil epidemiológico da malária no Estado do Pará em 1999 com base numa série histórica de dez anos (19891999). Informe Epidemiológico do SUS, v. 11, no. 2, p. 69-77, 2002. https://doi.org/ 10.5123/S0104-16732002000200003

Ferreira, G. M.; Zan, R. A.; Ramos, L. J.; Sousa, R. A. A. R.; Meneguetti, D. U. O. Panorama epidemiológico da malária no Município de Ariquemes, Rondônia, Amazônia Ocidental: um inquérito de seis anos (2005 a 2010). Revista de Epidemiologia, Controle e Infectologia, v. 2, no. 4, p. 128-132, 2012. https://doi.org/10.17058/reci.v2i4.2768

Granzoto, A. C. G.; Pessoa, A. M.; Silva Junior, N. J. Epidemiologia dos casos de malária em Sinop-MT (2003-2012). Estudos, v. 42, no. 4, p. 527-538, 2015. https://doi.org/10.18224/ est.v42i4.4371

Jarude, R.; Trindade, R.; Tavares-Neto, J. Malária em grávidas de uma maternidade pública de Rio Branco (Acre, Brasil). Revista Brasileira Ginecologia e Obstetrícia, v. 25, no. 3, p. 149-154, 2003. 
Loiola, C. C. P.; Silva, C. J. M.; Tauil, P. L. Controle da malária no Brasil: 1965 a 2001. Revista Panamericana de Salud Pública, v. 11, no. 4, p. 235-244, 2002.

Marques, A. C.; Gutierrez, H. C. Combate à malária no Brasil: evolução, situação atual e perspectivas. Revista da Sociedade Brasileira de Medicina Tropical, v. 27, p. 91-108, 1994.

Mesquita, E. M.; Muniz, T. F.; Sousa, A. L. S.; Brito, C. X. L.; Nunes, S. C. M.; Grisotto, M. A. G. Levantamento epidemiológico da malária no Estado do Maranhão, Brasil nos anos de 2007 a 2012. Revista de Ciência em Saúde, v. 15, no. 1, p. 11-18, 2013.

Miguel, R. B. Estudo da infecção por Plasmodium spp no Município de Guapimirim, Estado do Rio de Janeiro. Rio de Janeiro, Fundação Oswaldo Cruz, Instituto Oswaldo Cruz, 2011. (Dissertação de mestrado).

Monteiro, M. R. C. C.; Ribeiro, M. C.; Fernandes, S. C. Aspectos clínicos e epidemiológicos da malária em um hospital universitário de Belém, Estado do Pará, Brasil. Revista Pan-Amazônica de Saúde, v. 4, no. 2, p. 33-43, 2013. https://doi.org/ 10.5123/S2176-62232013000200005

OPAS - Organización Panamericana de la Salud. Actualización Epidemiológica: Aumento de malaria en las Américas. Available from: <https://www.paho.org/hq/ index.php?option=com_docman\&task=doc_vi ew\&Itemid=270\&gid=43437\&lang=es $>$.

Accessed in: Aug. 01, 2018.

Parente, A. T.; Souza, E. B.; Ribeiro, J. B. M. A ocorrência de malária em quatro municípios do Estado do Pará, de 1988 a 2005, e sua relação com o desmatamento. Acta Amazônica, v. 42, no. 1, p. 41-48, 2012. https://doi.org/10.1590/S0044-596720120 00100005

Parise, E. V.; Araújo, G. C.; Castro, J. G. D. Situação epidemiológica da malária no Estado do Tocantins, Brasil, a partir da emancipação política e administrativa, 1989 a 2009. Epidemiologia e Serviços de Saúde, v. 21, no. 1, p. 129-140, 2012. https://doi.org/10.5216/rpt.v41i4.21710

Renault, C. S.; Bastos, F. A.; Filgueira, J. P. P. S.; Filgueira, J.P.P.S.; Homma, T. K.
Epidemiologia da malária no Município de Belém-Pará. Revista Paraense de Medicina, v. 21, no. 3, p. 19-23, 2007.

RIPSA - Rede Interagencial de Informações para a Saúde. Indicadores e Dados Básicos para a Saúde no Brasil. Índice parasitário anual (IPA) de malária. Available from: <http://www.ripsa.org.br/fichasIDB/pdf/fic ha_D.4.pdf>. Accessed on: Aug. 01, 2018.

Sánchez, C. A. C.; Chirino, M. J. G.; Rondón, A. V.H. Malaria congénita: estudio retrospectivo 2000-2011. Hospital Menca de Leoni. Ciudad Guayana-Estado Bolívar. Archivos Venezolanos de Puericultura y Pediatría, v. 75, no. 4, p. 96-99, 2012.

Santos, I. G.; Silva, R. S. U. Malária autóctone no Município de Rio Branco. Revista PanAmazônica de Saúde, v. 2, no. 4, p. 31-37, 2011. https://doi.org/10.5123/S217662232011000400005

Silva Santelli, A. C. F.; Damasceno, C. P.; Peterka, C. L.; Marchesini, P. B. Plano de eliminação de malária no Brasil. Fase 1 Malária falciparum. Brasília: Ministério da Saúde, 2016.

Sousa, J. R.; Santos, A. C. F.; Almeida, W. S.; Alarado, K. V. P.; Magno, L. D.; Rocha, J. A. M.; Pimentel, Z. N. S. Situação da malária na Região do Baixo Amazonas, Estado do Pará, Brasil, de 2009 a 2013: um enfoque epidemiológico. Revista Pan-Amazônica de Saúde, v. 6, no. 4, p.39-47, 2015. https://doi.org/10.5123/S2176-622320150 00400006

Tobón-Castaño, A.; Solano, M.; Sánchez, L. G. A.; Trujillo, S. B. Retardo no crescimento intrauterino, baixo peso ao nascer e prematuridade em recém-nascidos de grávidas com malária, na Colômbia. Revista da Sociedade de Brasileira de Medicina Tropical, v. 44, no. 3, p. 364-370, 2011. https://doi.org/10.1590/S0037-86822011 005000030

Ujvari, S. C. Meio ambiente \& epidemias. São Paulo: SENAC, 2014.

WHO - World Health Organization. World Malaria Report 2015. Washington: WHO, 2015. Available from: <http://www.who.int/ malaria/publications/world-malaria-report2015/report/en/>. Accessed on: May 15, 2018. 